\title{
Volatility of Macro Fundamentals across Exchange Rate Regimes:
}

\section{A Theoretical Exploration}

\author{
Hong $\mathrm{Wu}$ (Corresponding Author) \\ Department of Economics, University of St. Thomas \\ 2115 Summit Avenue, St. Paul, MN 55105, USA
}

Tel: 1-651-962-5667 E-mail: hwu2@stthomas.edu

Jimmy Ran

Department of Economics, Lingnan University

8 Castle Peak Road, Tuen Mun, Hong Kong

Tel: 852-26167207Ｅ-mail: jimmyran@ln.edu.hk

Received: June 30, 2011

Accepted: July 14, 2011

Published: November 1, 2011

doi:10.5539/ijef.v3n6p79

URL: http://dx.doi.org/10.5539/ ijef.v3n6p79

\begin{abstract}
This paper seeks a novel theoretical support for the analysis of volatility changes in macro fundamentals with a shift in exchange rate regime by incorporating Rotemberg's sticky-price adjustment rule and the forward-looking Taylor monetary reaction function into a stochastic dynamic Mundell-Fleming framework. The model predicts that, with flexible prices, output and real exchange rate exhibit the same variability after a shift. Interest rates are more volatile and the inflation rate is less volatile under the float. With fixed prices, inflation and the interest rate volatility are unchanged. The real exchange rate is more volatile under the float. Volatility in output and money co-moves. Our theoretical findings shed some light on the diverse empirical results in the literature-exchange rate regime shift does not lead to a uniform change in macro volatility; country-specific factors such as the degree of price rigidity, among others, are influential as well.
\end{abstract}

Keywords: Linked/Flexible Regime, Volatility, Macroeconomic Fundamentals, Mundell-Fleming Model, Taylor Monetary Reaction Function

\section{Introduction}

Many arguments have been made both for and against fixed exchange rate systems. Monetary models of the nominal exchange rate maintain that stabilization of the exchange rate is achieved at the cost of a more volatile money supply and resulting volatility in the real exchange rate. The major advantages of flexible rates are the increased independence of government policies in stabilizing macroeconomic fundamentals and the less painful adjustment mechanism to trade imbalances. The Mundell-Fleming model (Mundell, 1963 and Fleming, 1962) on the other hand, argues that fixed exchange rates are superior to floating rates because fixed rates can reduce trade and investment uncertainties. Standard classical or international real business cycle models imply that a shift in exchange rate regime has no real effects on the behavior of macroeconomic aggregates.

It seems indisputable that volatility of the real exchange rate dramatically rises with a switch of exchange rate system from the peg to the float (Mussa 1986, Baxter and Stockman 1989, Fratianni and von Hagen 1990, Artis and Taylor 1994, Flood and Rose 1995, Kanas 2005).

$\mathrm{E}, \mathrm{Gu}$, and Yang (2009) find that the real exchange rate volatility of the Chinese yuan (RMB) and the Malaysian ringgit (MYR) are lower under the pegged regime. Bleaney and Francisco (2010) examine real effective exchange rate volatility for 90 countries using monthly data from January 1990 to June 2006 . They show that an independent float adds at least $45 \%$ to the standard deviation of the real effective exchange rate, relative to a conventional peg. The results are robust to alternative volatility measures and to sample selection bias. Craighead (2010) examine the behavior of the US-UK real exchange rate over the period 1794-2005 and show a consistent pattern of higher real exchange rate volatility under floating nominal rates.

Empirical findings, however, about the behavior of the other macroeconomic aggregates are mixed and controversial. Evidences fall into approximately three main categories. 
The first category documents that floating rates yield more stability. Frenkel and Mussa (1980) show that for a given set of random shocks, fixing the exchange rate induces higher volatility of interest rates, money supplies, prices and output. Both Hutchison and Walsh (1992) and Kim (2000) find that in Japan output appears to be more stable after it moved to the floating exchange rate system. Osakwe and Schembri (2002) show that a flexible exchange rate produces lower output variability in Mexico. Bergvall (2005) simulate hypothetical macroeconomic developments under different hypothetical regimes in Sweden during the period 1974-1994. The results show that output is substantially more volatile under the hypothetical fixed exchange rate regimes. Using a sample of 42 developing countries, Hoffmann (2007) assesses whether the responses of real GDP, the trade balance and the real exchange rate to world output and world real interest rate shocks differ across exchange rate regimes. It shows that there are significant differences in the variability of macroeconomic aggregates under fixed and flexible exchange rate regimes. Flexible exchange rates act as a 'shock absorber' and mitigate the effects of external shocks more effectively than fixed exchange rate regimes. Hurnik, Tuma, and Vavra (2010) show that euro area accession is likely to increase inflation volatility in the Czech Republic. Petreski (2010) explore the relationship between exchange-rate regimes and output volatility. The empirical investigation covers the post-Bretton-Woods era (1976-2006) and includes 169 countries. It is found that sufficiently large terms-of-trade shocks will spur output volatility under fixed, limited-flexible and flexible exchange-rate regime as compared with a floating regime, but the marginal effect is estimated to be the most severe under a peg (longer than five years). Alba, Su, and Chia (2011) examine the role of three different types of monetary policy rules in mitigating or exacerbating the effects of a negative foreign output shock on key macroeconomic variables of a small open economy and find that small open economies that follow fixed exchange rate regime tend to stabilize real exchange rate at the expense of substantial instability in the real economy.

The second category is in favor of fixed rates. Flood and Hodrick (1986) show that an imperfectly credible exchange rate may result in higher volatility of domestic interest rates and asset prices than what would be the case in a permanently fixed and credible regime. Fratianni and von Hagen (1990) document that the EMS (European Monetary System) has had a stabilizing impact on nominal and real exchange rates, inflation and output. Bodart and Reding (1999) inspect the behavior of domestic daily returns on bond and stock markets of the ERM (Exchange Rate Mechanism) and non-ERM countries and provide substantial evidence that a credible peg is associated with a decline in bond market volatility. Cheung and Westermann (2001) study the effect of exchange rate regime choices on equity markets and show that since the introduction of the Euro, the volatility of the German stock index have fallen significantly relative to those of the U.S. index. Using a multivariate regime switching framework on the period 1921-2002, Kanas (2005) finds that the US/UK real exchange rate and real interest rate are jointly characterized by high volatility during periods of floating exchange rates, and by low volatility during periods of fixed exchange rates.

Von Furstenberg (2006) explores the potential stability benefits from monetary union by examining volatility of PPP-GDP per capita and per hour under various de facto exchange rate regimes. It finds that, for Mexico unlike Canada, volatility is much greater during periods when the nominal dollar exchange rate changes appreciably than when it is quasi-pegged. This finding suggests that the stability benefits of monetary union are greatest for emerging-market countries inside an economically integrating region and non-existent for financially highly advanced countries.

Morales-Zumaquero and Sosvilla-Rivero (2008) analyze the impact of the establishment of the European Monetary System (EMS) on a number of macroeconomic variables, such as exchange rates, money, interest rates and prices for member countries participating in the Exchange Rate Mechanism (ERM). Instability is examined in terms of multiple structural breaks in the variance of the series. Results indicate that there is some evidence of structural breaks in volatility across investigated variables, with the realignments in the ERM playing a significant role in reducing volatility in some countries and sub-periods. In this regard, the results tend to support the hypothesis that the EMS has contributed to reducing macroeconomic volatility in member countries.

Schnabl (2009) cross country panel estimations provide evidence for a negative impact of the exchange rate volatility on growth in both Emerging Europe and East Asia. Parts of this negative growth effect can be associated with exchange rate volatility caused by macroeconomic instability.

The third category has raised a puzzle and has been labeled "the empirical regularities" in the subject matter. Baxter and Stockman (1989) are unable to find systematic differences in the volatility of real macroeconomic aggregates (output, consumption, and trade flows) when they compare the pre-1973 and post-1973 periods for a sample of OECD and non-OECD countries. Flood and Rose (1995) examine the typical OECD countries and conclude that the volatility of money, output, stock return and inflation does not change much across exchange rate regimes. This suggests that there is no clear tradeoff between reduced exchange rate volatility and macroeconomic stability. 
Sopraseuth (2003) investigates the consequences of membership to the European Monetary System and finds that the volatility puzzle turns out to be a robust stylized fact. Kasman and Ayhan (2006) find little evidence on the statistically significant difference between the exchange rate regimes, particularly under "de facto" classification. Macroeconomic variables exhibit similar volatilities across alternative exchange rate regimes in Turkey. Overall, "de facto" regime neutrality is stronger than "de jure" regime neutrality.

Moccero (2011) document that the adoption of floating exchange rate has been accompanied by lower volatility in the monetary stance in Brazil, Colombia, and Mexico, higher inflation volatility in Brazil and Colombia. The change in the monetary regime has not yet resulted in a reduction in output volatility in these countries.

These diverse and conflicting empirical results have posed a pressing challenge on the theoretical explanations and therefore motivated our endeavor in this direction. (Note 1) This paper attempts to explore theoretically the variability of key macroeconomic fundamentals under alternative exchange rate systems in a stochastic dynamic Mundell-Fleming framework following Obstfeld (1985) and Mark (2001). The solutions of the model offer a simple and direct testing mechanism for volatility comparison.

The remainder of the paper is organized as follows. Section 2 lays out the model. Section 3 derives the propositions. Section 4 concludes.

\section{The Model}

In this paper we investigate the influence of different exchange rate regimes on macroeconomic stability in a modern stochastic dynamic version of the Mundell-Fleming framework, following Obstfeld (1985) and Mark (2001). The framework assumes that goods prices adjust slowly, whereas asset markets- including the foreign exchange market- are continuously in equilibrium. The presence of nominal rigidities in goods market opens the way for nominal shocks to have real effects therefore policy-makers play a major role in the economy.

\subsection{The Framework of the Stochastic Dynamic Mundell-Fleming Model}

Let $y_{t}{ }^{d}$ be aggregate demand, $y_{t}$ potential production, $s_{t}$ the nominal exchange rate (domestic currency per unit of foreign currency), $p_{t}$ the domestic price level, $i_{t}$ the domestic nominal interest rate, $m_{t}$ the nominal money stock, and $\mathrm{E}_{\mathrm{t}}(\mathrm{X})$ the mathematical expectation of the random variable $\mathrm{X}$, conditioned on date-t information. All variables except the interest rates are in natural logarithms. Variables with a superscript * represent foreign variables.

The IS curve is

$$
y_{t}^{d}=\eta\left(s_{t}-p_{t}\right)-\sigma\left[i_{t}-\left(E_{t} p_{t+1}-p_{t}\right)\right]+d_{t},
$$

where $d_{t}$ is an aggregate demand shock and $i_{t}-\left(E_{t} p_{t+1}-p_{t}\right)$ is the ax ante real interest rate. Demand for home goods depends positively on the real exchange rate $s_{t}+p_{t}{ }^{*}-p_{t}$. We study a small open economy so that the log world price level $p_{t}^{*}$ is set to 0 . Domestic goods demand depends negatively on the real interest rate through the investment-saving channel. The parameters $\eta$ and $\sigma$ (as are all other parameters) are set to be positive.

The LM curve is

$$
m_{t}-p_{t}=y_{t}{ }^{d}-\lambda i_{t}
$$

where the income elasticity of money demand is assumed to be 1 and the interest rate elasticity equals $\lambda>0$.

Capital market equilibrium is given by uncovered interest rate parity:

$$
\mathrm{i}_{\mathrm{t}}=\mathrm{i}_{\mathrm{t}}^{*}+\mathrm{E}_{\mathrm{t}} \mathrm{s}_{\mathrm{t}+1}-\mathrm{s}_{\mathrm{t}},
$$

The sticky-price adjustment rule used in the standard stochastic dynamic Mundell-Fleming framework (Obstfeld, 1985 and Mark 2001) is

$$
\mathrm{p}_{\mathrm{t}}=\theta \mathrm{E}_{\mathrm{t}-1} \tilde{\mathrm{p}}_{\mathrm{t}}+(1-\theta) \tilde{\mathrm{p}_{\mathrm{t}}},
$$

where $\widetilde{p}_{\mathrm{t}}$ is the "shadow" value associated with the flexible-price equilibrium and $\theta$ is an adjustment coefficient. According to equation (4)', goods prices display rigidity for at most one period.

In this paper, we adopt a different sticky-price adjustment rule following Rotemberg (1982) which has been shown to be more consistent with the stylized facts. (Note 2)

$$
\mathrm{p}_{\mathrm{t}}=\theta \mathrm{p}_{\mathrm{t}-1}+(1-\theta) \tilde{\mathrm{p}}_{\mathrm{t}},
$$

At date $t$, part of the firms set their price level exactly equal to last period's actual price $\mathrm{p}_{\mathrm{t}-1} \quad$ while the rest of the firms set the prices such that the markets are in equilibrium, namely they allow prices to be flexible, $p_{t}=\widetilde{p}_{t}$. Prices are perfectly flexible if $\theta=0$, and they are completely fixed if $\theta=1$. Intermediate degrees of price rigidity are characterized by $0<\theta<1$. This modification distinguishes our model from the standard Mundell-Fleming framework. 
Under fully flexible prices, $p_{t}=\widetilde{p}_{t}(\theta=0)$, the goods market is continuously in equilibrium: $y_{t}{ }^{d}=y_{t}$. Using equation (1) and the fact that potential production $\mathrm{y}_{\mathrm{t}}$ is exogenous, we get

$$
y_{t}=\eta\left(s_{t}-\tilde{p_{t}}\right)-\sigma\left[i_{t}-\left(E_{t} \tilde{p_{t+1}}-\tilde{p_{t}}\right)\right]+d_{t}
$$

The exogenous state variables are potential production $\mathrm{y}_{\mathrm{t}}$, the demand shock $\mathrm{d}_{\mathrm{t}}$ and the foreign interest rate $\mathrm{i}_{\mathrm{t}}{ }^{*}$, and they are governed by unit-root processes;

$$
\begin{array}{r}
\mathrm{y}_{\mathrm{t}}=\mathrm{y}_{\mathrm{t}-1}+\mathrm{z}_{\mathrm{t}}, \\
\mathrm{d}_{\mathrm{t}}=\mathrm{d}_{\mathrm{t}-1}+\mathrm{u}_{\mathrm{t}}, \\
\mathrm{i}_{\mathrm{t}}{ }^{*}=\mathrm{i}_{\mathrm{t}-1}{ }^{*}+\mathrm{v}_{\mathrm{t}},
\end{array}
$$

where $\mathrm{z}_{\mathrm{t}} \sim$ i.i.d. $\mathrm{N}\left(0, \sigma_{\mathrm{z}}{ }^{2}\right), \mathrm{u}_{\mathrm{t}} \sim$ i.i.d. $\mathrm{N}\left(0, \sigma_{\mathrm{u}}{ }^{2}\right)$ and $\mathrm{v}_{\mathrm{t}} \sim$ i.i.d. $\mathrm{N}\left(0, \sigma_{\mathrm{v}}{ }^{2}\right)$. Cross correlations among $\mathrm{z}_{\mathrm{t}}, \mathrm{u}_{\mathrm{t}}$ and $\mathrm{v}_{\mathrm{t}}$ are all zero.

Note that in our model, the nominal money stock $\mathrm{m}_{\mathrm{t}}$ is an endogenous variable whereas the standard Mundell-Fleming framework treats money as an exogenous state variable.

\subsection{The Model under a Fixed Exchange Rate Regime}

Under a fixed exchange rate system, $\mathrm{s}_{\mathrm{t}+1}=\mathrm{s}_{\mathrm{t}}=\mathrm{E}_{\mathrm{t}} \mathrm{s}_{\mathrm{t}+1}$. Substituting this into equation (3), the uncovered interest rate parity condition, we end up with equation $(9)_{\mathrm{L}}$. The subscript $\mathrm{L}$ refers to the linked exchange rate regime.

$$
i_{t}=i_{t}^{*},
$$

In order to maintain a fixed exchange rate, the domestic nominal interest rate is set to be equal to the nominal interest rate in a foreign country. Otherwise, with perfect capital mobility, the discrepancy between the local interest rate $i_{t}$ and the foreign interest rate $i_{t}{ }^{*}$ would cause capitals flow in and out, which could break the link. Monetary authorities in the home country thus lose ability to control the economy via monetary policies.

Equations (1) through (8) and (9) $\mathrm{L}$ provide a complete modified Mundell-Fleming model under a linked exchange rate regime. Let $\pi_{t} \equiv\left(p_{t}-p_{t-1}\right)$ be the inflation rate and let $q_{t}$ be the real exchange rate $\left(s_{t}-p_{t}\right)$. Using lag operator $L$ (for example, $\mathrm{L} \mathrm{p}_{\mathrm{t}}=\mathrm{p}_{\mathrm{t}-1}$ ), we solve for solutions (see Appendix 1).

$$
\begin{gathered}
\Delta \mathrm{i}_{\mathrm{t}}=\mathrm{v}_{\mathrm{t}}, \\
\Delta \mathrm{y}_{\mathrm{t}}^{\mathrm{d}}=\frac{1-\theta}{1-\theta \mathrm{L}}\left(\sigma \mathrm{v}_{\mathrm{t}}+\mathrm{z}_{\mathrm{t}}-\mathrm{u}_{\mathrm{t}}\right)+\mathrm{u}_{\mathrm{t}}-\sigma \mathrm{v}_{\mathrm{t}}-\frac{\theta(1-\theta)}{1-\theta \mathrm{L}}\left\{\frac{\sigma^{2}}{\eta}\left(\mathrm{v}_{\mathrm{t}}-\mathrm{v}_{\mathrm{t}-1}\right)+\frac{\sigma}{\eta}\left[\mathrm{z}_{\mathrm{t}}-\mathrm{z}_{\mathrm{t}-1}-\left(\mathrm{u}_{\mathrm{t}}-\mathrm{u}_{\mathrm{t}-1}\right)\right]\right\}, \\
\Delta \mathrm{q}_{\mathrm{t}}=\frac{1-\theta}{1-\theta \mathrm{L}}\left(\frac{\sigma \mathrm{v}_{\mathrm{t}}+\mathrm{z}_{\mathrm{t}}-\mathrm{u}_{\mathrm{t}}}{\eta}\right), \\
\pi_{\mathrm{t}}=-\frac{1-\theta}{1-\theta \mathrm{L}}\left(\frac{\sigma \mathrm{v}_{\mathrm{t}}+\mathrm{z}_{\mathrm{t}}-\mathrm{u}_{\mathrm{t}}}{\eta}\right), \\
\Delta \mathrm{m}_{\mathrm{t}}=\pi_{\mathrm{t}}+\Delta \mathrm{y}_{\mathrm{t}}^{\mathrm{d}}-\lambda \Delta \mathrm{i}_{\mathrm{t}},
\end{gathered}
$$

Under the linked regime, equation $(10)_{\mathrm{L}}$ indicates that the change in the domestic nominal interest rate at date $t$ is determined solely by date $t$ shocks to the foreign interest rate, since $i_{t}$ is set to be equal to $i_{t}{ }^{*}$ and $i_{t}{ }^{*}$ is assumed to follow a random walk process.

Slow adjustment in goods prices enables past shocks to play a role in the current economy. Under the linked regime, monetary authorities are unable to respond to these shocks. Note that, from equations $(11)_{\mathrm{L}}$ through $(14)_{\mathrm{L}}$, the output growth rate $\Delta \mathrm{y}_{\mathrm{t}}^{\mathrm{d}}$, the growth rate of the real exchange rate $\Delta \mathrm{q}_{\mathrm{t}}$, inflation rate $\pi_{\mathrm{t}}$, and the growth rate of money $\Delta \mathrm{m}_{\mathrm{t}}$ depend on domestic supply and demand shocks and foreign interest rate shocks at time $t$ as well as those shocks previous to time $\mathrm{t}$.

\subsection{The Model under a Flexible Exchange Rate Regime}

When monetary authorities do not intervene in the foreign exchange market, the nominal exchange rate is free to vary over time and domestic authorities regain control over monetary policy. Numerous studies have considered Taylor rules, which relate the interest rate to inflation and the output gap, as monetary policy guidelines both for the United States and for other countries (see Taylor 1993, Judd and Rudebusch 1998, Clarida, Gali and Gertler 1998 and Faust, Rogers and Wright 2001 for examples).

As in Faust, Rogers and Wright (2001), we use a forward-looking Taylor rule (equation (9) below) as the domestic monetary reaction function. The subscript $\mathrm{F}$ refers to the flexible exchange rate regime.

$$
i_{t}=\bar{i}+\alpha\left(E_{t} p_{t+1}-p_{t}\right)+\gamma\left(y_{t}^{d}-y_{t}\right),
$$


where $\bar{i}$ is a constant (containing the targeted interest rate and inflation rate information), $E_{t} p_{t+1}-p_{t}$ is the expected inflation rate and $y_{t}^{d}-y_{t}$ is the output gap. This kind of monetary reaction function indicates that the central bank is targeting inflation (or the forecasted inflation), but it is doing so with at least some separate attention paid to the output gap, and it is using the short-term interest rate as the instrument of monetary policy. (Note 3)

When the parameter $\alpha$ is greater than one, an increase in inflation causes the real interest rate to rise, a desired instrument to apply. Clarida, Gali and Gertler (2000) show that the estimate of $\alpha$ is significantly greater than one and the estimate of $\gamma$ is marginally significantly positive but less than one. Faust, Rogers and Wright (2001) confirm similar results. These findings are consistent with our preconditions in the next section to solve the model.

Equations (1) through (8) and (9) F provide a complete modified Mundell-Fleming system under a flexible exchange rate regime.

In order to ensure the system is stable, the following condition must hold. (Note 4)

$$
\rho=\theta-\alpha \theta+\alpha-1+\theta \gamma \eta>0
$$

The solutions then are as follows:

$$
\begin{gathered}
\Delta \mathrm{i}_{\mathrm{t}}=\frac{\rho+1-\theta}{\rho} \mathrm{v}_{\mathrm{t}}, \\
\Delta \mathrm{y}_{\mathrm{t}}^{\mathrm{d}}=\frac{\theta \eta}{\rho} \mathrm{v}_{\mathrm{t}}+\mathrm{z}_{\mathrm{t}} \\
\Delta \mathrm{q}_{\mathrm{t}}=\frac{\theta \eta+\sigma \rho}{\rho \eta} \mathrm{v}_{\mathrm{t}}+\frac{\mathrm{z}_{\mathrm{t}}-\mathrm{u}_{\mathrm{t}}}{\eta}, \\
\pi_{\mathrm{t}}=\frac{1-\theta}{\rho}\left(\mathrm{i}_{\mathrm{t}}^{*}-\overline{\mathrm{i}}\right), \\
\Delta \mathrm{m}_{\mathrm{t}}=\pi_{\mathrm{t}}+\Delta \mathrm{y}_{\mathrm{t}}^{\mathrm{d}}-\lambda \Delta \mathrm{i}_{\mathrm{t}},
\end{gathered}
$$

Note that under a flexible regime, all the macroeconomic fundamentals depend only on domestic supply and demand shocks as well as foreign interest rate shocks at time $t$. Shocks previous to time t do not play a role as they do under the linked regime. Independent monetary policies (as stated in the Taylor rule) are effective in eliminating past shocks to the current economy.

\section{Propositions}

The influence of alternative exchange rate systems on the stability of macroeconomic fundamentals can be studied now by looking at the solutions from the classical point of view when goods prices are perfectly flexible and also from the Keynesian point of view where goods prices are rigid.

Chadha (1990) investigates the relationships between the degree of price stickiness and the variability of output and the real exchange rate in an open economy with flexible exchange rates and capital mobility. It shows that as prices become more inflexible, the variability of output declines and the relationship between the variability of the real exchange rate and that of output is nonmonotonic; that is, as the variability of the real exchange rate increases, the variability of output first declines and then increases. Such relationships under the fixed exchange rate system were not examined. In contrast, this paper explores the change in macro volatility across exchange rate regimes assuming prices are either fixed or perfectly flexible.

\subsection{The Classical Case $(\theta=0)$}

When $\theta=0$, the precondition (equation A2.15) to solve the above model is $\alpha>1$. (Note 5) Substituting $\theta=0$ into equations $(10)_{\mathrm{L}}$ through $(14)_{\mathrm{L}}$, and equations $(10)_{\mathrm{F}}$ through $(14)_{\mathrm{F}}$, we end up with five pairs of comparisons for key macroeconomic fundamentals under the flexible and the linked exchange rate regimes.

Pair 1: $\left\{\begin{array}{c}\left(\Delta \mathrm{y}_{\mathrm{t}}^{\mathrm{d}}\right)_{\mathrm{F}}=\mathrm{z}_{\mathrm{t}} \\ \left(\Delta \mathrm{y}_{\mathrm{t}}^{\mathrm{d}}\right)_{\mathrm{L}}=\mathrm{z}_{\mathrm{t}}\end{array}\right.$, Pair 2: $\left\{\begin{array}{c}\left(\Delta \mathrm{i}_{\mathrm{t}}\right)_{\mathrm{F}}=\frac{\alpha}{\alpha-1} \mathrm{v}_{\mathrm{t}} \\ \left(\Delta \mathrm{i}_{\mathrm{t}}\right)_{\mathrm{L}}=\mathrm{v}_{\mathrm{t}}\end{array}\right.$,

Pair 3: $\left\{\begin{array}{l}\left(\Delta q_{t}\right)_{F}=\frac{\sigma}{\eta} v_{t}+\frac{z_{t}-u_{t}}{\eta} \\ \left(\Delta q_{t}\right)_{L}=\frac{\sigma}{\eta} v_{t}+\frac{z_{t}-u_{t}}{\eta}\end{array}\right.$, Pair 4: $\left\{\begin{array}{c}\left(\pi_{\mathrm{t}}\right)_{\mathrm{F}}=\frac{1}{\alpha-1}\left(\mathrm{i}_{\mathrm{t}}^{*}-\overline{\mathrm{i}}\right) \\ \left(\pi_{\mathrm{t}}\right)_{\mathrm{L}}=-\left(\frac{\sigma}{\eta} \mathrm{v}_{\mathrm{t}}+\frac{\mathrm{z}_{\mathrm{t}}-\mathrm{u}_{\mathrm{t}}}{\eta}\right)\end{array}\right.$, 
Pair 5: $\left\{\begin{array}{l}\left(\Delta \mathrm{m}_{\mathrm{t}}\right)_{\mathrm{F}}=\frac{1}{\alpha-1}\left(\mathrm{i}_{\mathrm{t}}^{*}-\overline{\mathrm{i}}\right)+\mathrm{z}_{\mathrm{t}}-\frac{\lambda \alpha}{\alpha-1} \mathrm{v}_{\mathrm{t}} \\ \left(\Delta \mathrm{m}_{\mathrm{t}}\right)_{\mathrm{L}}=-\left(\frac{\sigma}{\eta} \mathrm{v}_{\mathrm{t}}+\frac{\mathrm{z}_{\mathrm{t}}-\mathrm{u}_{\mathrm{t}}}{\eta}\right)+\mathrm{z}_{\mathrm{t}}-\lambda \mathrm{v}_{\mathrm{t}}\end{array}\right.$.

The first pair of solutions shows that the output growth rate under the float is exactly equal to the one under the link and hence the variability of the output growth should be the same under both exchange rate regimes. If prices are free to change, the goods market is always in equilibrium $\left(y_{t}^{d}=y_{t}\right)$, actual production is determined purely by the economy's potential capacity to produce. The choice of the exchange rate regime does not have a real effect on $\Delta \mathrm{y}_{\mathrm{t}}^{\mathrm{d}}$.

As indicated by the second pair of solutions, the variance of $\Delta \mathrm{i}_{\mathrm{t}}$ under the link is equal to $\sigma_{\mathrm{v}}{ }^{2}$, whereas the variance of $\Delta \mathrm{i}_{\mathrm{t}}$ under the float is equal to $(\alpha / \alpha-1)^{2} \sigma_{\mathrm{v}}{ }^{2}$. Given that $\alpha>1$, the nominal interest rate is more stable under the linked exchange rate regime.

Regarding the real exchange rate in the third pair, there is no difference in the volatility across two alternative regimes suggested by the solutions, $\left(\Delta \mathrm{q}_{\mathrm{t}}\right)_{\mathrm{F}}=\left(\Delta \mathrm{q}_{\mathrm{t}}\right)_{\mathrm{L}}$. It seems difficult to judge from the fourth pair under which exchange rate system $\pi_{\mathrm{t}}$ has greater volatility. But we get some clue from the third pair, the real exchange rate $\mathrm{q}_{\mathrm{t}}$. Since $q_{t}=s_{t}-p_{t}$, and the nominal exchange rate $s_{t}$ is obviously more volatile under the flexible regime, so in order to satisfy an equal variability in the real exchange rate $q_{t}$, it must be true that under the flexible exchange rate regime, the inflation rate $\pi_{\mathrm{t}}$ is less volatile. Domestic authorities are able to stabilize the inflation rate by their own independent monetary policies while they cannot do so under a linked exchange rate system.

Without further assumptions on the parameters, it is difficult to compare money volatility across two regimes from the fifth pair. According to equation $(14)_{\mathrm{F}}$, we know that variability of the money stock depends on the variability of the output growth, the nominal interest rates and the inflation rate. The overall effect is ambiguous.

Proposition I summarizes these findings and provides us with interesting predictions.

\section{Proposition I}

If goods prices are perfectly flexible and if the monetary authority's reaction function is a forward-looking Taylor rule under a flexible exchange rate regime, then:

(I a) Variance $\left(\Delta \mathrm{q}_{\mathrm{t}}\right)_{\mathrm{L}}=$ Variance $\left(\Delta \mathrm{q}_{\mathrm{t}}\right)_{\mathrm{F}}$;

(I b) Variance $\left(\Delta \mathrm{i}_{\mathrm{t}}\right)_{\mathrm{L}}<$ Variance $\left(\Delta \mathrm{i}_{\mathrm{t}}\right)_{\mathrm{F}}$;

(I c) Variance $\left(\pi_{\mathrm{t}}\right)_{\mathrm{L}}>$ Variance $\left(\pi_{\mathrm{t}}\right)_{\mathrm{F}}$;

(I d) Variance $\left(\Delta \mathrm{y}_{\mathrm{t}}^{\mathrm{d}}\right)_{\mathrm{L}}=\operatorname{Variance}\left(\Delta \mathrm{y}_{\mathrm{t}}^{\mathrm{d}}\right)_{\mathrm{F}}$;

(I e) The change in the variance of the money stock is ambiguous.

\subsection{The Keynesian Case $(\theta=1)$}

When $\theta=1$, the precondition (equation A2.15) to solve the model is $\gamma \eta>0$. (Note 6)

Substituting $\theta=1$ into equations $(10)_{\mathrm{L}}$ through $(14)_{\mathrm{L}}$, and equations $(10)_{\mathrm{F}}$ through $(14)_{\mathrm{F}}$, when goods prices are fixed, we again end up with five pairs of comparisons for key macroeconomic fundamentals under alternative exchange rate regimes.

Pair 1: $\left\{\begin{array}{r}\left(\Delta \mathrm{y}_{\mathrm{t}}^{\mathrm{d}}\right)_{\mathrm{F}}=\mathrm{z}_{\mathrm{t}}+\frac{1}{\gamma} \mathrm{v}_{\mathrm{t}} \\ \left(\Delta \mathrm{y}_{\mathrm{t}}^{\mathrm{d}}\right)_{\mathrm{L}}=\mathrm{u}_{\mathrm{t}}-\sigma \mathrm{v}_{\mathrm{t}}\end{array}, \quad\right.$ Pair 2: $\left\{\begin{array}{c}\left(\Delta \mathrm{i}_{\mathrm{t}}\right)_{\mathrm{F}}=\mathrm{v}_{\mathrm{t}} \\ \left(\Delta \mathrm{i}_{\mathrm{t}}\right)_{\mathrm{L}}=\mathrm{v}_{\mathrm{t}},\end{array} \quad\right.$ Pair 3: $\left\{\begin{array}{l}\left(\pi_{\mathrm{t}}\right)_{\mathrm{F}}=0 \\ \left(\pi_{\mathrm{t}}\right)_{\mathrm{L}}=0\end{array}\right.$,

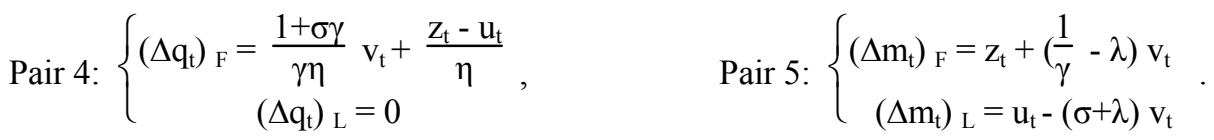

It is clear from the third pair of solutions that the inflation rate is stable and does not depend on the choice of the exchange rate regime. With the same (zero) variability of inflation under both regimes, the real exchange rate $\mathrm{q}_{t}\left(=\mathrm{s}_{\mathrm{t}}\right.$ - $p_{t}$ ) must be more variable under the float as indicated by the fourth pair.

It is interesting to find from the second pair that the variability of the nominal interest rate stays the same under both regimes and is fully determined by shocks to the foreign interest rate. As in Appendix 2, equation A2.17, $\mathrm{E}_{\mathrm{t}} \mathrm{s}_{\mathrm{t}+1}-\mathrm{s}_{\mathrm{t}}=$ $p_{t}-p_{t-1}$ under the flexible exchange rate regime. Expected variations in the nominal exchange rate next period are determined by the actual inflation rate this period. Given that prices are fixed, the zero inflation rate implies zero changes in the expected nominal exchange rate. The term $\mathrm{E}_{\mathrm{t}} \mathrm{S}_{\mathrm{t}+1}-\mathrm{S}_{\mathrm{t}}$ disappears in the uncovered interest rate parity, making $i_{t}$ equals $i_{t}^{*}$, like the case when the exchange rate is fixed. 
Without further knowledge on parameters $\gamma$ and $\sigma$ and more precise assumptions on the shocks in the first pair, it is unclear how the variability of the output growth rate responds to a shift in exchange rate regime. However, note that $\Delta \mathrm{m}_{\mathrm{t}}$ contains $\Delta \mathrm{y}_{\mathrm{t}}{ }^{\mathrm{d}}$ in its expression and $\Delta \mathrm{y}_{\mathrm{t}}{ }^{\mathrm{d}}$ is the only portion that is different over the two alternative regimes (Note 7). Our solutions predict that a shift in the exchange rate regime would have identical implications on the volatility of both fundamentals. The possibility that output and money do not exhibit systematic and dramatic change in their variability across exchange rate systems, the so called "stylized facts" by Flood and Rose (1995), is surely within the range of our predictions.

Proposition II summarizes the above findings.

\section{Proposition II}

If goods prices are fixed and if the monetary authority's reaction function is a forward-looking Taylor rule under a flexible exchange rate regime, then:

(II a) Variance $\left(\Delta \mathrm{q}_{\mathrm{t}}\right)_{\mathrm{L}}<$ Variance $\left(\Delta \mathrm{q}_{\mathrm{t}}\right)_{\mathrm{F}}$;

(II b) Variance $\left(\Delta \mathrm{i}_{\mathrm{t}}\right)_{\mathrm{L}}=$ Variance $\left(\Delta \mathrm{i}_{\mathrm{t}}\right)_{\mathrm{F}}$;

(II c) Variance $\left(\pi_{\mathrm{t}}\right)_{\mathrm{L}}=$ Variance $\left(\pi_{\mathrm{t}}\right)_{\mathrm{F}}$;

(II d) Variance $\left(\Delta \mathrm{y}_{\mathrm{t}}{ }^{\mathrm{d}}\right)$ and Variance $\left(\Delta \mathrm{m}_{\mathrm{t}}\right)$ co-move across exchange rate regimes.

Proposition I and II contribute to the literature by providing a clear and direct prediction, from a theoretical angle, on the change of the macro volatility with a shift in the exchange rate system. Our model demonstrates that the degree of price rigidity and the monetary policy rules play important roles. The regime shift alone does not fully explain the dynamics. Interestingly, Devereux (2000) documents analogous conclusions though drawn from a completely different setting. "The exchange rate regime has implications for both the volatility and mean of macroeconomic aggregates. But the effects of the exchange rate regime depend upon both the stance of monetary policy and the way in which the exchange rate is pegged". (Note 8)

\section{Concluding Remarks}

There is a large literature on the volatility of macro fundamentals since the breakdown of the Bretton Woods system. Would a fixed exchange rate arrangement stabilize the macro economy or create more variances instead? Does it matter at all? The empirical results are mixed and controversial. Each hypothesis seems to have received its own supporting evidences. We made an attempt in this paper to look for a theoretical guidance and have indeed found interesting predictions that are in line with the diverse empirical observations.

We integrate Rotemberg's (1982) sticky-price adjustment rule and a forward-looking Taylor monetary reaction function into a stochastic dynamic Mundell-Fleming framework. The model touches much of the macro economy - output, inflation, money, exchange rate and interest rate under both the float and the fixed regime. The variances of the macro fundamentals are rigorously calculated and compared across alternative exchange rate systems under the classical assumption of flexible prices and also the Keynesian assumption of fixed prices.

Our model predicts that, with flexible prices, output and the real exchange rate exhibit the same variability after a shift. Interest rates are more and the inflation rate is less volatile under the float. With fixed prices, inflation and the interest rate volatility are unchanged. The real exchange rate is more volatile under the float. Volatility in output and money co-moves. The propositions derived from our theoretical model demonstrate: 1) macro volatility does not change in any uniform direction with a shift in the exchange rate regime; it is impacted yet not fully explained by the shift. 2) Country-specific factors, especially the price adjustment process, play important roles as well. It is not surprising then why the empirical results do not converge.

\section{References}

Alba, Joseph D, Zheng Su, and Wai-Mun Chia. (2011). Foreign Output Shocks, Monetary Rules and Macroeconomic Volatilities in Small Open Economies. International Review of Economics and Finance 20, 71-81. http://dx.doi.org/10.1016/j.iref.2010.07.007

Artis, M.J. and M.P. Taylor. (1994). The Stabilizing Effect of the ERM on Exchange Rates and Interest Rates. Int. Monet. Fund Staff Pap. 41, 123-148, http://dx.doi.org/10.2307/3867487

Baxter, M. and A.C. Stockman. (1989). Business Cycles and the Exchange Rate Regime: Some International Evidence. Journal of Monetary Economics 23, 377-400, http://dx.doi.org/10.1016/0304-3932(89)90039-1

Bergvall, Anders. (2005). Exchange Rate Regimes and Macroeconomic Stability: The Case of Sweden. Oxford Economic Papers 57, 422-46, http://dx.doi.org/10.1093/oepgpi016 
Bleaney, Michael and Manuela Francisco. (2010). What Makes Currencies Volatile? An Empirical Investigation. Open Economies Review 21, 731-750. http://dx.doi.org/10.1007/s11079-009-9121-0

Bodart, Vincent and Paul Reding. (1999). Exchange Rate Regime, Volatility and International Correlations on Bond and Stock Markets. Journal of International Money and Finance 18, 133-151, http://dx.doi.org/10.1016/S0261-5606(98)00042-4

Chadha, Bankim. (1990). Real Exchange Rate and Output Variability: The Role of Sticky Prices. International Monetary Fund Staff Papers 37, 593-611, http://dx.doi.org/10.2307/3867266

Cheung, Yin-Wong and Frank Westermann. (2001). Equity Price Dynamics before and after the Introduction of the Euro: A Note. Multinational Finance Journal 5, 113-28.

Clarida, R., J. Gali and M. Gertler. (1998). Monetary Policy Rules in Practice: Some International Evidence. European Economic Review 42, 1033-1067, http://dx.doi.org/10.1016/S0014-2921(98)00016-6

Clarida, R., J. Gali and M. Gertler. (2000). Monetary Policy Rules and Macroeconomic Stability: Evidence and Some Theory. Quarterly Journal of Economics, 147-180, http://dx.doi.org/10.1162/003355300554692

Craighead, William D. (2010). Across Time and Regimes: 212 Years of the US-UK Real Exchange Rate. Economic Inquiry 48, 951-964, http://dx.doi.org/10.1111/j.1465-7295.2009.00243.x

Diego Moccero. (2011). Monetary Policy and Macroeconomic Stability in Latin America: The Cases of Brazil, Chile, Colombia and Mexico. Journal of International Money and Finance 30, 229-245. http://dx.doi.org/10.1016/j.jimonfin.2010.08.002

Devereux, M., (2000). A Simple Dynamic General Equilibrium Model of The Tradeoff Between Fixed And Floating Exchange Rates. C.E.P.R. Discussion Papers, CEPR Discussion Papers: 2403.

Duarte, Margarida. (2003). Why Don't Macroeconomic Quantities Respond to Exchange Rate Variability? Journal of Monetary Economics 50, 889-913, http://dx.doi.org/10.1016/S0304-3932(03)00035-7

E, Yongjian, Yanxiang Gu, and Chau-Chen Yang. (2009). Real Exchange Rate Behavior under Peg: Evidence from the Chinese RMB and Malaysian MYRReview of Pacific Basin Financial Markets and Policies 12, 141-158.

Faust, J., John H. Rogers and Jonathan H. Wright. (2001). An Empirical Comparison of Bundesbank and ECB Monetary Policy Rules. International Finance Discussion Papers, Number 705.

Flood, Robert P. and R.J. Hodrick. (1986). Real Aspects of Exchange Rate Regime Choice with Collapsing Fixed Rates. Journal of International Economics 21, 215-232, http://dx.doi.org/10.1016/0022-1996(86)90037-1

Flood, Robert P. and Andrew K. Rose. (1995). Fixing Exchange Rates: A Virtual Quest for Fundamentals. Journal of Monetary Economics 36, 3-37, http://dx.doi.org/10.1016/0304-3932(95)01210-4

Fleming, Marcus J. (1962). Domestic Financial Policies under Fixed and under Floating Exchange Rates. International Monetary Fund Staff Papers 9, 369-79, http://dx.doi.org/10.2307/3866091

Fratianni, M. and J. von Hagen. (1990). The European Monetary System Ten Years After. Carnegie Rochester Conf. Ser. Public Pol. 32, 173-242.

Frenkel, J.A. and M.L. Mussa. (1980). The Efficiency of Foreign Exchange Markets and Measures of Turbulence. American Economic Review 70, 374-381.

Hoffmann, Mathias. (2007). Fixed versus Flexible Exchange Rates: Evidence from Developing Countries.Economica 74, 425-449. http://dx.doi.org/10.1111/j.1468-0335.2006.00564.x

Hurnik, Jaromir, Zdenek Tuma, and David Vavra. (2010). The Euro Adoption Debate Revisited: The Czech Case. Czech Journal of Economics and Finance 60, 194-212.

Hutchison, M. and C. Walsh. (1992). Empirical Evidence on the Insulation Properties of Fixed and Flexible Exchange Rates: the Japanese Experience. Journal of International Economics 32, 241-263, http://dx.doi.org/ 10.1016/0022-1996(92)90019-G

Judd, J.P. and G.D. Rudebusch. (1998). Taylor's Rule and the Fed: 1970-1997. Federal Reserve Bank of San Francisco Economic Review 3, 3-16.

Kanas, Angelos. (2005). Regime Linkages in the US/UK Real Exchange Rate-Real Interest Differential Relation. Journal of International Money and Finance 24, 257-74, http://dx.doi.org/10.1016/j.jimonfin.2004.12.006

Kasman, Saadet and Duygu Ayhan. (2006). Macroeconomic volatility under alternative exchange rate regimes in Turkey. Central Bank Review 6, 37-58. 
Kim, Jongwoo. (2000). The Relationship between the Monetary Regime and Output Volatility: A Multivariate GARCH-M Model of the Japanese Experience, 1919-1996. Japan and the World Economy 12, 49-69, http://dx.doi.org/10.1016/S0922-1425(99)00024-9

Mark, Nelson C. (2001). International Macroeconomics and Finance: Theory and Econometric Methods. Blackwell Publishers.

Morales-Zumaquero, A and Simon Sosvilla-Rivero. (2008). Macroeconomic Instability in the European Monetary System? Applied Financial Economics18, 965-983. http://dx.doi.org/10.1080/09603100701367401

Mundell, Robert A. (1963). Capital Mobility and Stabilization Policy under Fixed and Flexible Exchange Rates. Canadian Journal of Economics and Political Science 29, 475-85, http://dx.doi.org/10.2307/139336

Mussa, Michael. (1986). Nominal Exchange Regimes and the Behavior of Real Exchange Rates: Evidence and Implications. Carnegie-Rochester Conference Series on Public Policy 25, 117-213, http://dx.doi.org/10.1016/0167-2231(86)90039-4

Obstfeld, Maurice. (1985). Floating Exchange Rates: Experience and Prospects. Brookings Papers on Economic Activity 2, 369-450, http://dx.doi.org/10.2307/2534443

Osakwe, Patrick N and Lawrence L. Schembri. (2002). Real Effects of Collapsing Exchange Rate Regimes: An Application to Mexico. Journal of International Economics 57, 299-325.

Petreski, Marjan. (2010). Exchange-Rate Regimes and Output Volatility: Empirical Investigation with Panel Data. International Journal of Monetary Economics and Finance 3, 69-99. http://dx.doi.org/10.1504/IJMEF.2010.030037

Rotemberg, Julio. (1982). Sticky Prices in the United States. Journal of Political Economy 90, 1187-1211, http://dx.doi.org/10.1086/261117

Rotemberg, Julio and Alberto Giovannini. (1989). Exchange Rate Dynamics with Sticky Prices: the Deutsche Mark, 1974-1982. Journal of Business and Economic Statistics 7, 169-78, http://dx.doi.org/10.2307/1391434

Rotemberg, Julio. (1996). Prices, Output, and Hours: An Empirical Analysis Based on A Sticky Price Model. Journal of Monetary Economics 37, 505-33, http://dx.doi.org/10.1016/0304-3932(96)01264-0

Schnabl, Gunther. (2009). Exchange Rate Volatility and Growth in Emerging Europe and East Asia. Open Economies Review 20, 565-587. http://dx.doi.org/10.1007/s11079-008-9084-6

Sopraseuth, Thepthida. (2003). Exchange Rate Regimes and International Business Cycles. Review of Economic Dynamics 6, 339-61, http://dx.doi.org/10.1016/S1094-2025(02)00017-0

Taylor, J.B. (1993). Discretion versus Policy Rules in Practice. Carnegie-Rochester Conference series on Public Policy 39, 195-214, http://dx.doi.org/10.1016/0167-2231(93)90009-L

von Furstenberg, George. (2006). Mexico versus Canada: Stability Benefits from Making Common Currency with USD? North American Journal of Economics and Finance 17, 65-78. http://dx.doi.org/10.1016/j.najef.2005.11.001

\section{Notes}

Note 1. Duarte (2003) develops a dynamic general equilibrium two-country model with segmented markets and local-currency pricing which can account quantitatively for the stylized fact described above in the third category. Nevertheless, the test of the model is based on a calibration by approximating numerically the stationary equilibrium. The model itself does not provide a direct guidance on the volatility comparison across exchange rate regimes.

Note 2. Rotemberg and Giovannini (1989) estimate the Deutsche mark/dollar exchange rate dynamics with sticky prices formed this way. The main results support the specified adjustment rule. In addition, Rotemberg (1996) shows that the same sticky-price-adjustment rule is consistent with a variety of facts in terms of the correlation of prices, hours, and output.

Note 3. Most central banks may not characterize their behavior in this way. However, the reason for the popularity of this kind of monetary policy rule is that it provides a good simple empirical representation of central bank behavior under a wide variety of monetary policy regimes.

Note 4. See Appendix 2, equation (A2.13) is a stochastic difference equation in $p_{t}-p_{t-1}$. Iterating forward on (A2.13), the solution for $\mathrm{p}_{\mathrm{t}}-\mathrm{p}_{\mathrm{t}-1}$ can be found by the present-value formula if the parameter,

$\frac{1-\alpha(1-\theta)+\gamma \sigma \theta}{\gamma \theta(\sigma+\eta)+\theta}$, on the term of $E_{t} p_{t+1}-p_{t}$, is less than one. This results in equation (A2.15), a precondition.

Note 5. Our precondition here is consistent with the results obtained by Clarida, Gali and Gertler (2000) and Faust, Rogers and Wright (2001). 
Note 6. We have set $\eta$ to be positive in Equation (1). $\gamma$ is positive as in Clarida, Gali and Gertler (2000) and Faust, Rogers and Wright (2001). When demand is above potential production, monetary authorities need to increase nominal interest rates to cool down the economy and eliminate the gap (Taylor rule). Lower interest rates indicated by a negative $\gamma$ will widen the gap and make the economy unstable.

Note 7. Based on the first and the fifth pair of solutions, rewrite $\Delta \mathrm{m}_{\mathrm{t}}$ as a function of $\Delta \mathrm{y}_{\mathrm{t}}{ }^{\mathrm{d}}$, we have

$$
\left\{\begin{array}{c}
\left(\Delta \mathrm{m}_{\mathrm{t}}\right)_{\mathrm{F}}=\left(\Delta \mathrm{y}_{\mathrm{t}}^{\mathrm{d}}\right)_{\mathrm{F}}-\lambda \mathrm{v}_{\mathrm{t}} \\
\left(\Delta \mathrm{m}_{\mathrm{t}}\right)_{\mathrm{L}}=\left(\Delta \mathrm{y}_{\mathrm{t}}\right)_{\mathrm{L}}-\lambda \mathrm{v}_{\mathrm{t}}
\end{array} .\right.
$$

Note 8. Devereux (2000) analyzes the positive and normative effects of alternative exchange rate regimes in a simple two-country sticky-price dynamic general equilibrium model with money, technology, and government spending shocks. The macro fundamentals modeled are consumption, capital stock, output, and employment.

\section{Appendix 1 Solving a Stochastic Dynamic Mundell-Fleming Model under a Fixed Exchange Rate Regime}

The model:

$$
\begin{aligned}
& \mathrm{y}_{\mathrm{t}}^{\mathrm{d}}=\eta\left(\mathrm{s}_{\mathrm{t}}-\mathrm{p}_{\mathrm{t}}\right)-\sigma\left[\mathrm{i}_{\mathrm{t}}-\left(\mathrm{E}_{\mathrm{t}} \mathrm{p}_{\mathrm{t}+1}-\mathrm{p}_{\mathrm{t}}\right)\right]+\mathrm{d}_{\mathrm{t}}, \\
& \mathrm{m}_{\mathrm{t}}-\mathrm{p}_{\mathrm{t}}=\mathrm{y}_{\mathrm{t}}^{\mathrm{d}}-\lambda \mathrm{i}_{\mathrm{t}}, \\
& \mathrm{i}_{\mathrm{t}}=\mathrm{i}_{\mathrm{t}}^{*}+\mathrm{E}_{\mathrm{t}} \mathrm{s}_{\mathrm{t}+1}-\mathrm{s}_{\mathrm{t}}, \\
& \quad \mathrm{p}_{\mathrm{t}}=\theta \mathrm{p}_{\mathrm{t}-1}+(1-\theta) \widetilde{\mathrm{p}_{\mathrm{t}}}, \\
& \quad \mathrm{y}_{\mathrm{t}}=\eta\left(\mathrm{s}_{\mathrm{t}}-\widetilde{\mathrm{p}}_{\mathrm{t}}\right)-\sigma\left[\mathrm{i}_{\mathrm{t}}-\left(\mathrm{E}_{\mathrm{t}} \tilde{\mathrm{p}_{\mathrm{t}+1}}-\widetilde{\mathrm{p}}_{\mathrm{t}}\right)\right]+\mathrm{d}_{\mathrm{t}}, \\
& \mathrm{y}_{\mathrm{t}}=\mathrm{y}_{\mathrm{t}-1}+\mathrm{z}_{\mathrm{t}}, \\
& \mathrm{d}_{\mathrm{t}}=\mathrm{d}_{\mathrm{t}-1}+\mathrm{u}_{\mathrm{t}}, \\
& \mathrm{i}_{\mathrm{t}}^{*}=\mathrm{i}_{\mathrm{t}-1}{ }^{*}+\mathrm{v}_{\mathrm{t}}, \\
& \quad \mathrm{i}_{\mathrm{t}}=\mathrm{i}_{\mathrm{t}}^{*}, \text { or } \mathrm{s}_{\mathrm{t}+1}=\mathrm{s}_{\mathrm{t}}=\mathrm{E}_{\mathrm{t}} \mathrm{s}_{\mathrm{t}+1},
\end{aligned}
$$

To solve the model:

$$
\text { Define } \widetilde{q}_{\mathrm{t}}=\mathrm{s}_{\mathrm{t}}-\widetilde{\mathrm{p}}_{\mathrm{t}}, \mathrm{q}_{\mathrm{t}}=\mathrm{s}_{\mathrm{t}}-\mathrm{p}_{\mathrm{t}},
$$

A1 indicates Appendix 1.

Substitute (3) into (5) and rearrange to give

$$
\tilde{\mathrm{q}}_{\mathrm{t}}=\frac{\mathrm{y}_{\mathrm{t}}-\mathrm{d}_{\mathrm{t}}}{\sigma+\eta}+\frac{\sigma}{\sigma+\eta}\left(\mathrm{i}_{\mathrm{t}}^{*}+\mathrm{E}_{\mathrm{t}} \tilde{\mathrm{q}}_{\mathrm{t}+1}\right),
$$

(A1.2) is a stochastic difference equation in $\widetilde{q}$. The solution is given by the present-value formula by iterating forward on (A1.2) since $\frac{\sigma}{\sigma+\eta}<1$.

$$
\tilde{\mathrm{q}}_{\mathrm{t}}=\frac{\sigma \mathrm{i}_{\mathrm{t}}^{*}+\mathrm{y}_{\mathrm{t}}-\mathrm{d}_{\mathrm{t}}}{\eta}
$$

By using a lag operator L in (4),

$$
\mathrm{p}_{\mathrm{t}}=\frac{1-\theta}{1-\theta \mathrm{L}} \widetilde{\mathrm{p}_{\mathrm{t}}}
$$

where $L p_{t}=p_{t-1}, L$ is equal to 1 when multiplied by a constant.

Rearrange (A1.1) to give

$$
\widetilde{p_{t}}=s_{t}-\widetilde{q}_{t}
$$

Substitute (A1.3), (A1.5) into (A1.4),

$$
\mathrm{p}_{\mathrm{t}}=\mathrm{s}_{\mathrm{t}}-\frac{1-\theta}{1-\theta \mathrm{L}} \frac{\sigma \mathrm{i}_{\mathrm{t}}^{*}+\mathrm{y}_{\mathrm{t}}-\mathrm{d}_{\mathrm{t}}}{\eta}
$$

Based on (A1.6), (6), (7), (8) and (9) $)_{\mathrm{L}}$ to find

$$
E_{t} p_{t+1}-p_{t}=-\frac{\theta(1-\theta)}{1-\theta L} \frac{\sigma v_{t}+z_{t}-u_{t}}{\eta}
$$

Substitute (A1.6), (9) $\mathrm{L}$ and (A1.7) into (1),

$$
\mathrm{y}_{\mathrm{t}}{ }^{\mathrm{d}}=\frac{1-\theta}{1-\theta \mathrm{L}}\left(\sigma \mathrm{i}_{\mathrm{t}}^{*}+\mathrm{y}_{\mathrm{t}}-\mathrm{d}_{\mathrm{t}}\right)+\mathrm{d}_{\mathrm{t}}-\sigma \mathrm{i}_{\mathrm{t}}^{*}-\frac{\theta(1-\theta)}{1-\theta \mathrm{L}} \frac{\sigma^{2} \mathrm{v}_{\mathrm{t}}+\sigma\left(\mathrm{z}_{\mathrm{t}}-\mathrm{u}_{\mathrm{t}}\right)}{\eta},
$$

Based on (A1.1) and (A1.6), 
$\mathrm{q}_{\mathrm{t}}=\frac{1-\theta}{1-\theta \mathrm{L}} \quad \frac{\sigma \mathrm{i}_{\mathrm{t}}{ }^{*}+\mathrm{y}_{\mathrm{t}}-\mathrm{d}_{\mathrm{t}}}{\eta}$

Now it is straightforward to find the solutions - equations (10) L through (14) L

Appendix 2 Solving a Stochastic Dynamic Mundell-Fleming Model under a Flexible Exchange Rate Regime

The model:

$$
\begin{aligned}
& y_{t}^{d}=\eta\left(s_{t}-p_{t}\right)-\sigma\left[i_{t}-\left(E_{t} p_{t+1}-p_{t}\right)\right]+d_{t}, \\
& m_{t}-p_{t}=y_{t}^{d}-\lambda i_{t}, \\
& \quad i_{t}=i_{t}^{*}+E_{t} s_{t+1}-s_{t}, \\
& p_{t}=\theta p_{t-1}+(1-\theta) \widetilde{p_{t}}, \\
& y_{t}=\eta\left(s_{t}-\widetilde{p}_{t}\right)-\sigma\left[i_{t}-\left(E_{t} \tilde{p_{t+1}}-\tilde{p}_{t}\right)\right]+d_{t}, \\
& y_{t}=y_{t-1}+z_{t}, \\
& d_{t}=d_{t-1}+u_{t}, \\
& i_{t}^{*}=i_{t-1}^{*}+v_{t}, \\
& i_{t}=\bar{i}+\alpha\left(E_{t} p_{t+1}-p_{t}\right)+\gamma\left(y_{t}{ }^{d}-y_{t}\right),
\end{aligned}
$$

To solve the model:

Define $\tilde{\mathrm{q}}_{\mathrm{t}}=\mathrm{s}_{\mathrm{t}}-\widetilde{\mathrm{p}}_{\mathrm{t}}, \mathrm{q}_{\mathrm{t}}=\mathrm{s}_{\mathrm{t}}-\mathrm{p}_{\mathrm{t}}$,

A2 indicates Appendix 2.

Substitute (3) into (5) and rearrange to give

$$
\tilde{\mathrm{q}}_{\mathrm{t}}=\frac{\mathrm{y}_{\mathrm{t}}-\mathrm{d}_{\mathrm{t}}}{\sigma+\eta}+\frac{\sigma}{\sigma+\eta}\left(\mathrm{i}_{\mathrm{t}}^{*}+\mathrm{E}_{\mathrm{t}} \underset{\mathrm{q}_{\mathrm{t}+1}}{\tilde{q}}\right)
$$

(A2.2) is a stochastic difference equation in $\widetilde{\mathrm{q}}$. The solution is given by the present-value formula by iterating forward on (A2.2) since $\frac{\sigma}{\sigma+\eta}<1$.

By using a lag operator L in (4),

$$
\tilde{\mathrm{q}}_{\mathrm{t}}=\frac{\sigma \mathrm{i}_{\mathrm{t}}^{*}+\mathrm{y}_{\mathrm{t}}-\mathrm{d}_{\mathrm{t}}}{\eta}
$$

$$
\tilde{\mathrm{p}}_{\mathrm{t}}=\frac{1-\theta \mathrm{L}}{1-\theta} \quad \mathrm{p}_{\mathrm{t}}
$$

where $L p_{t}=p_{t-1}$, $L$ is equal to 1 when multiplied by a constant.

From (A2.4),

Rearrange (A2.1) to give

$$
\begin{aligned}
\tilde{p}_{t}-p_{t} & =\frac{\theta}{1-\theta}\left(p_{t}-p_{t-1}\right), \\
E_{t} & \tilde{p_{t}+1}-\tilde{p_{t}}=\frac{1-\theta L}{1-\theta}\left(E_{t} p_{t+1}-p_{t}\right),
\end{aligned}
$$

$$
\mathrm{s}_{\mathrm{t}}=\widetilde{\mathrm{p}}_{\mathrm{t}}+\widetilde{\mathrm{q}}_{\mathrm{t}}
$$

Substitute (A2.3) into (A2.7),

$$
\mathrm{s}_{\mathrm{t}}=\widetilde{\mathrm{p}}_{\mathrm{t}}+\frac{\sigma \mathrm{i}_{\mathrm{t}}{ }^{*}+\mathrm{y}_{\mathrm{t}}-\mathrm{d}_{\mathrm{t}}}{\eta}
$$

Based on (A2.8), (6), (7) and (8) find

$$
\mathrm{E}_{\mathrm{t}} \mathrm{s}_{\mathrm{t}+1}-\mathrm{s}_{\mathrm{t}}=\mathrm{E}_{\mathrm{t}} \tilde{\mathrm{p}_{\mathrm{t}+1}}-\tilde{\mathrm{p}_{\mathrm{t}}},
$$

Substitute (A2.6) into (A2.9),

$$
E_{t} s_{t+1}-s_{t}=\frac{1-\theta L}{1-\theta}\left(E_{t} p_{t+1}-p_{t}\right)
$$

Subtract (5) from (1),

$$
y_{t}^{d}-y_{t}=\eta\left(\widetilde{p_{t}}-p_{t}\right)+\sigma\left[E_{t} p_{t+1}-p_{t}-\left(E_{t} \tilde{p_{t+1}}-\widetilde{p}_{t}\right)\right],
$$

Substitute (A2.5) and (A2.6) into (A2.11),

$$
y_{t}^{d}-y_{t}=\frac{(\sigma+\eta) \theta}{1-\theta}\left(p_{t}-p_{t-1}\right)-\frac{\sigma \theta}{1-\theta}\left(E_{t} p_{t+1}-p_{t}\right),
$$


Substitute (A2.10) into (3), substitute (A2.12) into (9) $)_{\mathrm{F}}$, and rearrange to give

$$
\left(p_{t}-p_{t-1}\right)=\frac{1-\theta}{\gamma \theta(\sigma+\eta)+\theta} \quad\left(i_{t}^{*}-\bar{i}\right)+\frac{1-\alpha(1-\theta)+\gamma \sigma \theta}{\gamma \theta(\sigma+\eta)+\theta}\left(E_{t} p_{t+1}-p_{t}\right)
$$

(A2.13) is a stochastic difference equation in $p_{t}-p_{t-1}$. The solution is given by the present-value formula by iterating forward on (A2.13) as long as

$$
\frac{1-\alpha(1-\theta)+\gamma \sigma \theta}{\gamma \theta(\sigma+\eta)+\theta}<1
$$

From (A2.14), the precondition to solve the model is

$$
\rho=\theta-\alpha \theta+\alpha-1+\theta \gamma \eta>0
$$

Given that (A2.15) is true, solve (A2.13),

Based on (A2.16) and (6), (7), (8),

$$
p_{t}-p_{t-1}=\frac{1-\theta}{\rho} \quad\left(i_{t}^{*}-\bar{i}\right)
$$

$$
\mathrm{E}_{\mathrm{t}} \mathrm{p}_{\mathrm{t}+1}-\mathrm{p}_{\mathrm{t}}=\mathrm{p}_{\mathrm{t}}-\mathrm{p}_{\mathrm{t}-1},
$$

Substitute (A2.17) into (A2.10),

$$
\mathrm{E}_{\mathrm{t}} \mathrm{s}_{\mathrm{t}+1}-\mathrm{s}_{\mathrm{t}}=\mathrm{p}_{\mathrm{t}}-\mathrm{p}_{\mathrm{t}-1}
$$

From (A2.8) and (A2.5),

$$
\mathrm{q}_{\mathrm{t}}=\mathrm{s}_{\mathrm{t}}-\mathrm{p}_{\mathrm{t}}=\frac{\theta}{1-\theta}\left(\mathrm{p}_{\mathrm{t}}-\mathrm{p}_{\mathrm{t}-1}\right)+\frac{\sigma \mathrm{i}_{\mathrm{t}}^{*}+\mathrm{y}_{\mathrm{t}}-\mathrm{d}_{\mathrm{t}}}{\eta},
$$

Everything has been solved in terms of $p_{t}-p_{t-1},(A 2.16)$ provides the solution for $p_{t}-p_{t-1}$.

Now it is straightforward to find the solutions- equations $(10)_{\mathrm{F}}$ through $(14)_{\mathrm{F}}$. 